\title{
Doğu Akdeniz Bölgesinde İleri Çıkmış Nohut (Cicer arietinum L.) Hatlarında Kışık Ekimde Verim ve Kalite Özelliklerinin Değerlendirilmesi

\author{
Dürdane MART ${ }^{1}$, Meltem TÜRKERİ ${ }^{1}$, Ramazan $_{\text {AKIN }}^{2}$, Evren ATMACA ${ }^{2}$, \\ Derya YÜCEL ${ }^{3}$, Tolga KARAKÖY ${ }^{4}$, Gülgün ÖKTEM ${ }^{5}$, Süreyya Emre \\ DUMLU $^{6}$, Nejda ÇANKAYA ${ }^{7}$, Sezgin MART $^{8}$, Canan CAN $^{9}$
} ÖZ

Bu araştırma, Akdeniz iklim koşullarında 2014 ve 2015 yetiştirme döneminde ileri çıkmış hatlar 2 yıl süreyle ekilerek verim ve verimle ilgili bazı özellikler incelenmiştir. Denemeler, Doğu Akdeniz Tarımsal Araştırma Enstitüsü araştırma alanlarında yürütülmüş; çalışmada 17 hat ve 3 çeşit kontrol kullanılarak 20 genotipli olarak deneme planlanmıştır. Yapılan çalışmada Doğu Akdeniz bölgesi için genotiplerden kışlık ekime uygunluk, Ascochyta hastalığına toleransll1ık yönünde değerlendirmeler yapılmıştır. Araştırmanın yürütüldüğü 2014 yılında, nohut genotiplerinden elde edilen en yüksek ve en düşük tane verim değerleri 102,2-353,7 kg/da arasında; 2015 yılında elde edilen en yüksek ve en düşük tane verim değerleri 43,4- 405,4 kg/da arasında değişim göstermiştir. İki yıllık ortalama değerler bakımından da 98,15-379,56 kg/da arasında değerler tespit edilmiştir. Ascochyta yanıklık hastalığı yoğun olduğu yıllarda verimde kayıplara neden olmuştur. Her iki yetiştirme sezonu (2014 ve 2015) kalite değerleri bakımından deneme ortalama protein analiz değerleri en yüksek EN 1788 çeşidinden \%22,04, en düşük değer ise İnci çeşidinden \%19,74 değerleri elde edilmiştir. Ortalama değerler göz önünde bulundurulduğunda EN 1683, FLIP 01-24 C hatları kuru ağılık, yaş ağılık, su alma kapasitesi, yaş hacim, şişme kapasitesi bakımından diğer çeşitlere göre yüksek değerleri vererek ön plana çıkmıştır.

Anahtar kelimeler: Nohut, kışlık ekim, adaptasyon ve kalite

\section{Evaluation of yield and quality parameters for the promising winter chickpea (Cicer arietinum $\mathbf{L}$.) lines from the Eastern Mediterranean region} \section{ABSTRACT}

This research was conducted to evaluate the promising chickpea lines for their yield and quality paramaters under the Mediterranean winter conditions. The study took place in the Eastern Mediterranean Agricultural Research Institute, Adana during 2014 and 2015. In this study, 20 genotypes including 17 chickpea lines and 3 chickpea varieties were examined for their suitability to winter sowing conditions and their tolarance to Ascochyta disease. The highest and the lowest yield was observed as $353,7 \mathrm{~kg} / \mathrm{da} 102,2 \mathrm{~kg} / \mathrm{da}$ respectively in 2014 and observed as $43,4 \mathrm{~kg} / \mathrm{da}$ and $405,4 \mathrm{~kg} / \mathrm{da}$ respectively in 2015 . The avarage yield of two years was ranged between $98,15 \mathrm{~kg} / \mathrm{da}$ and $379,56 \mathrm{~kg} / \mathrm{da}$. The yield loss was occured during the growing years which Ascochyta blight was present and intense. The highest avarage protein content of two years was observed from the variety 'EN 1788' with $22,04 \%$ and the lowest avarage protein content was observed from the variety 'Inci'

\footnotetext{
Yayın Kuruluna Geliş Tarihi: 27.05.2021

Kabul Tarihi: 24.12.2021

${ }^{1}$ Doğu Akdeniz Tarımsal Araştırma Enstitüsü-Adana

${ }^{2}$ Geçit KuşağıTarımsal Araştırma Enstitüsü-Eskişehir

${ }^{3}$ Şırnak Üniversitesi Ziraat Fakültesi-Şırnak

${ }^{4}$ Cumhuriyet Üniversitesi Tarım Bilimleri ve Teknoloji Fakültesi-Sivas

${ }^{5}$ Harran Üniversitesi Ziraat Fakültesi-Urfa

${ }^{6}$ Doğu Anadolu Tarımsal Araştırma Enstitüsü-Erzurum

${ }^{7}$ Karadeniz Tarımsal Araştırma Enstitüsü-Samsun

${ }^{8}$ Crop Science, Üniversity of Hohenheim -Stuttgard

${ }^{9}$ Gaziantep Üniversitesi Fen Edebiyat Fakültesi-Gaziantep

*E-posta: durdanemart@yahoo.com
} 


\section{Doğu Akdeniz Bölgesinde İleri Çıkmış Nohut (Cicer arietinum L.) Hatlarında Kışlık Ekimde Verim ve Kalite Özelliklerinin Değerlendirilmesi}

with 19,74\%. The lines 'EN 1683' and 'FLIP 01-24 C' were highly promising for the parameters such as dry weight, wet weight, water intake capacity, wet volume and swelling capacity.

Keywords: Chickpea, Winter sowing, Adaptation and Quality

ORCID ID (Yazar sırasına göre)

0000-0002-2944-1227， 0000-0001-5225-967X，0000-0002-9955-9482，0000-0001-5072-8612, 0000-0002-7865-9900, 0000-0002-5428-1907, 0000-0002-7669-5801, 0000-0003-0154-8927, 0000-0001-5897-3583, 0000-0002-8597-6269, 0000-0002-0473-1914

\section{Giriş}

Ülkemizde nohut (Cicer arietinum L.), insan beslenmesindeki en temel besin kaynaklarındandır. Nohut, yemeklik kullanıldığ gibi leblebilik olarak da değerlendirilen önemli bir kültür bitkisidir. Yüksek protein ve lif içeriği ile sağlıklı bir besin maddesidir. Nohutun ülkemizdeki ekim alanı 517.785 ha ve üretimi ise 630.000 ton olup, birim alandan alınan tane verimi ise $122.00 \mathrm{~kg} / \mathrm{da}$ 'dır. Bu veriler ile nohut, baklagiller içerisinde önemli bir yere sahiptir (FAO, 2021). Nohut bitkisi tüketim ve üretim açısından değerlendirildiğinde yemeklik tane baklagil grubu içerisinde en fazla tarımı yapılan türdür. Ülkemizde ve Dünya'da nohut üretimini kısitlayan en önemli biyotik stres faktörü Antraknoz (Ascochyta rabiei) ve Fusarium solgunluk (Fusarium oxysporum f.sp. ciceris' in) hastalığıdır. $\mathrm{Bu}$ hastalıklar nohut üretiminin sürekliliğini ve verimini olumsuz yönde etkilemektedir. Nohut tane iriliği ile Ascochyta yanıklığı arasında ters ilişki bulunmaktadır. Tane iriliği arttıkça hastalığa hassaslık, tane küçüldükçe dayanıklık artmaktadır. Bu nedenle Ascochyta yanıklığına toleranslı ve iri taneli nohut çeşitlerinin geliştirilmesi için etmen populasyonunun ve bitki materyallerinin çok iyi bilinmesi gerekmektedir. Hastalık nedeniyle üretimde önemli verim ve kalite kayıpları meydana gelmektedir. Hastalığın mücadelesinde kullanılan kültürel yöntemler verimin düşmesine sebep olmaktadır. Kimyasal yöntemler ekonomik değildir ve aynı zamanda çevre ve insan sağlığına da zararları vardır. Mücadele etmenin en ekonomik ve etkili olan yolu hastalığa karşı genetik olarak dayanıklı yeni çeşitlerin geliştirilmesidir. Ascochyta yanıklı̆̆ 1 hastalık etmenine dayanıklı/toleranslı nohut çeşitlerinin geliştirilerek sertifikalı tohumluklarının çiftçinin hizmetine sunulması gerekmektedir. Islah çalışmalarının süreklik arz etmesi hatta zorunlu olmasi nedeniyle, çalışılması ve çalışmaların devam ettirilmesi gerekmektedir. Çünkü zaman içerisinde çeşitlerin dayanıklılık geni kırılabilmektedir. Klasik 1slah yöntemleriyle birlikte modern sslah yöntemlerinin de birlikte çalışılması bizi ileri taşıyacaktır.

Çeşitlerin dayanıklılığın/toleranslılı̆̆ın stabil olmaması, zaman içerisinde istenilen özelliklerinin kaybedilmesi önemli bir problemdir. Yürütülen bu proje çalışması ile bölgeye uygun çeşitlerin geliștirilmesi, üretimin ve kalitenin arttırılması, kışlık ekimlerde yer bulabilmeleri, yüksek verimli, hastalı ve zararlilara dayanıklı/toleranslı çeşitlerin belirlenmesi amacı güdülmüştür.

\section{Materyal ve Yöntem}

Araştırmada, bölgede yapılan Nohut 1slah çalışmalarında ileri çıkmış hatlarının adaptasyonu ve hastalık toleranslilık amaciyla planlanan deneme için 17 adet nohut genotipi ve 3 kontrol ile 2014-2015 yetiştirme dönemlerinde Adana lokasyonunda kışlık olarak ekimleri yapılarak değerlendirilmiştir. Gül ve ark. (2006), Bakoğlu (2009), Nohut bitkisinin kışlık olarak yetiştirilme amacıyla yürüttükleri çalışmada kış koşullarına dayanıklılığın standart çeşitte $\% 55.42$, diğer hatlarda ise \%70.91 ile \%78.75 arasında değiştiğini, başta tane verimi olmak üzere kışlık nohut ile ilgili bir çok özelliğin yazlık ekimlere göre daha avantajll, ayrıca verim ve makinalı hasada uygunluk açısından kışlık ekimlerin yine daha avantajlı olabileceğini bildirmişlerdir.

$\mathrm{Bu}$ araştırmada denemeler, sıra arası $45 \mathrm{~cm}$, sıra üzeri $8 \mathrm{~cm}$ olacak şekilde, $5 \mathrm{~m}$ uzunluğundaki 4 sıraya ( $9 \mathrm{~m}^{2}$ lik parsellere), üç tekerrürlü, kışlık olarak ekimler Aralık ayında yapılmıştır. Ekim öncesi dekara 2-3 kg N, 5-6 kg $\mathrm{P}_{2} \mathrm{O}_{5}$ gelecek şekilde gübreleme uygulanmış olup, Antraknoz yanıklığı hastalığına toleransları belirlemek için, çiçeklenme ve bakla bağlama dönemlerinde 


\section{Doğu Akdeniz Bölgesinde İleri Çıkmış Nohut (Cicer arietinum L.) Hatlarında Kışlık Ekimde Verim ve Kalite Özelliklerinin Değerlendirilmesi}

gerekli hastalık okumaları yapılmıştır. Özkan ve ark. (2015), Türkiye'de nohut yetiştirilen bölgelerdeki Ascochyta yanıklık etmeni olan Didymella rabiei'nin hastalık şiddetinin belirlenmesi için nohut ekimi yapılan tarlalardaki hastalık şiddet durumlarını 1-9 skalasına göre değerlendirmişlerdir.

2014 y1lında denemenin ekiminden sonra Aralık ve Ocak aylarında yağışların düşük ve uzun yıllar ortalamasının altında gerçekleşmesi kuraklık stresi olmasına; Kasım-Temmuz döneminde yağış miktarının dengesiz dağılımı olmasına rağmen; çiçeklenme ve bakla bağlama dönemi olan Mart ve Nisan aylarında düşen yağış miktarının ve sıcaklık ve nem oranlarının uygun olması nedeniyle Ascocyhta yanıklığı hastalığ 1 çok görülmemiştir. 2015 yılında ise, ekimden sonra Kasım, Aralık ve Ocak aylarında uzun yıllara göre yağış miktarının düşük olmasına ragmen, nohut tarımı için yeterli yağış düşmüştür. Bu yetiştirme sezonunda çiçeklenme dönemi olan Mart $(115,81 \mathrm{~mm})$ ayında yağ 1 ş yoğunluğu nedeniyle, Ascocyhta yanıklığı hastalığ 1 yoğunluğu artmıştır. Mayıs $(81,02 \mathrm{~mm})$ ayındaki yoğun yağışlar da bakla bağlama dönemi olması nedeniyle Ascocyhta yanıklığı hastalığından dolayı hassas çeşitlerde kayıplar yaşanmıştır. Yağış miktarı dağlımının düzensiz, düşük veya yüksek olması bitkileri strese sokmuş ve aynı zamanda da Ascocyhta yanıklığı hastalığının yoğunluğunda etkili olmuştur. Tivoli ve Banniza (2007), Ascochyta spp.'nin Ascochyta yanıklığı etmeni olduğunu açıklamışlardır. Bunun yanı sıra nohutta görülen Ascochyta yanıklığının belirtilerini, bitkinin toprak üstünde bulunan tüm aksamlarında benzer şekilde görüldüğünü ve hastalığın birkaç etmene (mevsimlere, iklim koşullarına ve ülkelere) bağlı olarak farklılık gösterdiğini tespit etmişlerdir. Sicaklık ve nem değerleri ise uzun y1llara paralel değerler göstermiştir (Tablo1).

2014 ve 2015 her iki yetiştirme sezonunda nohut genotiplerinde kalite analizleri için, hasat sonrası denemelerdeki tekerrürler birleştirilerek iyice harman yapılıp kalite için örnekler alınmıştır.

Çizelge 1. Adana ili 2013-2014; 2014-2015 ve uzun y1llar iklim değerleri

\begin{tabular}{|c|c|c|c|c|c|c|c|c|c|}
\hline \multirow[t]{2}{*}{ Aylar } & \multicolumn{3}{|c|}{ Ortalama Sicaklık $\left(\mathrm{C}^{0}\right)$} & \multicolumn{3}{|c|}{ Yağış (mm) } & \multicolumn{3}{|c|}{ Nisbi nem (\%) } \\
\hline & Uz.Y1l & $2013-2014$ & $2014-2015$ & Uz.Y11 & 2013-2014 & $2014-2015$ & Uz.Y1l & $2013-2014$ & $2014-2015$ \\
\hline Kasım & 15.3 & 17,7 & 14,76 & 67,2 & 1,0 & 36,06 & 63 & 57,5 & 54,8 \\
\hline Aralık & 11.1 & 10,4 & 13,0 & 118,1 & 12,2 & 50,05 & 66 & 42,7 & 71,6 \\
\hline Ocak & 9.7 & 11,48 & 8,9 & 111,7 & 28,19 & 56,39 & 66 & 69,58 & 66,3 \\
\hline Şubat & 10.4 & 10,84 & 10,9 & 92,8 & 18,54 & 90,68 & 66 & 56,90 & 70,1 \\
\hline Mart & 13.3 & 15,06 & 13,9 & 67,9 & 56,09 & 115,81 & 66 & 65,55 & 64,6 \\
\hline Nisan & 17.5 & 17,68 & 15,8 & 51,4 & 18,56 & 7,88 & 69 & 66,94 & 62,5 \\
\hline May1s & 21.7 & 21,26 & 21,7 & 46,7 & 22,36 & 81,02 & 67 & 70,39 & 64,3 \\
\hline Haz. & 25.6 & 24,03 & 24,2 & 22,4 & 50,04 & 0 & 66 & 68,19 & 69,1 \\
\hline Tem. & 27,7 & 28,23 & 28,0 & 5,4 & 0,25 & 0 & 68 & 72,58 & 69,3 \\
\hline
\end{tabular}

\section{Bulgular ve Tartışma}

Nohut Genotipleri verim ve Morfolojik özellikleri

2014 ve 2015 yetiştirme sezonlarında, Doğu Akdeniz bölge verim denemesine ilişkin ortalama değerler ve oluşan gruplar Tablo 2'de verilmektedir.

Tablodan görüleceği üzere, 2014 yetiştirme sezonunda çiçeklenme gün sayısı, ilk bakla yüksekliği, 100 tane ağırlığı ve tane verimi bakımından çeşitler arasında istatistiki düzeyde önemli farklılık bulunmakta olup en yüksek ve en düşük değerler sırasıyla 58.6-64.73 gün, 18.3$27.2 \mathrm{~cm}, 34.4-50.2 \mathrm{~g}$ ve $102.2-353.7 \mathrm{~kg} / \mathrm{da}$ 'dır. En erkenci nohut çeşidi Hasanbey ve EN 1788 (56.8 gün) hattı olurken bunu, FLIP 01-24C (59.0 gün) nohut hattının izlediği saptanmıştır. Bakla bağlama gün sayısı ve bitki boyu bakımından ise çeşitler arasında önemli bir fark bulunmamaktadır. En düşük bakla bağlama gün 


\section{Doğu Akdeniz Bölgesinde İleri Çıkmış Nohut (Cicer arietinum L.) Hatlarında Kışlık Ekimde Verim ve Kalite Özelliklerinin Değerlendirilmesi}

sayısına sahip nohut çeşidi Hasanbey (63.3 gün) olurken onu, FLIP 05-150C (73.3 gün), FLIP 05150C (73.3 gün) ve EN 1751 (73.3 gün) nohut hatlarının izledikleri saptanmıştır. En yüksek bitki boyu değerine sahip nohut hatt1 $95.5 \mathrm{~cm}$ ile ÜNHB-2010-52 olurken onu, ÜNHB-2010-95 $(89.5 \mathrm{~cm})$, ÜNHB-2010-52 $(87.2 \mathrm{~cm})$ ve EN $1685(84.7 \mathrm{~cm})$ nohut hatlarının izledikleri saptanmıştır. Azkan ve ark. (1999), 10 nohut hattı ile kışlık ve yazlık olarak farklı ekim zamanlarında yapmış oldukları araştırmalarında; ekim zamanı $\mathrm{x}$ çeșit interaksiyonunun bitkide ana dal sayısı dışında tüm özellikleri için istatistiki olarak önemli çıktığını bildirmişler, ayrıca ekim zamanlarının bitkide ana dal sayısı ve biyolojik verim üzerine önemli etkisinin bulunmadığını açıklamışlardır. Mart ve ark. (2003), 170 adet nohut populasyonun karakterizasyonu amaciyla yapılan çalışmada, ana bileşen analizi sonuçlarına göre 1slah programlarında önemle üzerinde durulan ve verimi doğrudan etkileyen bitkisel karakterlerden bir bakladaki tohum sayısı, bir bitkide bakla sayıs1, olgunluk gün sayısı, tane verimi ve bitki başına tane veriminin birinci ana bileşen vektöründe pozitif etki göstermişlerdir. $\mathrm{Bu}$ durum eldeki yerel nohut materyalinin verim komponentleri açısından taşıdığ önemi açıkça göstermektedir (Mart ve ark., 2001).

2015 y1lı yetiştirme sezonunda çiçeklenme gün sayıs1, bakla bağlama gün sayısı ve bitki boyu bakımından çeşitler arasında istatistiki düzeyde bir farklılık bulunmamaktadır (Tablo 2). En erkenci nohut çeşidi Seçkin (108.0 gün) olurken bunu, FLIP 01-24C hatt1 (109.3 gün) ve Hasanbey (109.0 gün) nohut çeşidinin izledikleri görülmektedir. En düşük bakla bağlama süresine Seçkin (124.3 gün) nohut çeşidi sahip olurken bunu Hasanbey (125.7) ve FLIP 01-24C (126.0 gün) nohut hat/çeşidinin izledikleri belirlenmiştir. En yüksek bitki boyu değeri FLIP 05-150C $(78.3 \mathrm{~cm})$ nohut hattından elde edilirken, bunu EN 1823 (76.6 cm), EN 1800 $(72.2 \mathrm{~cm})$ ve Hasanbey $(72.2 \mathrm{~cm})$ nohut hat/çeşidinin izledikleri belirlenmiştir. 20142015 yetiştirme sezonunda bitki boylarının daha düşük olmasının en önemli nedenlerinden birisi, iklim faktörlerine bağlı olarak yoğun bir antaknoz yanıklığı hastalığının görülmesi ve bitkilerin gelişiminin olumsuz etkilenmesi olarak belirlenmiştir. İlk bakla yüksekliği, 100 tane ağırlığı ve verim değerleri bakımından ise çeșitler arasında önemli farklılıklar olup en düşük ve en yüksek değerler sirasıyla 20.5-38.8 $\mathrm{cm}$ ile EN 1751 ve Seçkin çeşitlerinden, 32.845.7 gram ile EN 1823 ve FLIP 01-24 c çeşitlerinden, 43.4-405.4 kg/da ile ÜNHB-201097 ve İnci çeşitlerinden elde edilmiştir. Singh ve ark. (1995), 30 nohut çeşidinde yaptıkları korelasyon ve path analizinde tane verimi üzerinde en etkili özelliğin bitkide bakla sayısı olduğunu, özelliklerin büyük bir kısmının da bitkide bakla sayısı üzerinden dolaylı etki yaptığını belirlemişlerdir. En önemli seleksiyon kriterlerinin baklada tane sayısı ve bitkide bakla sayıs1 olduğunu ifade etmișlerdir. Katıyar ve Singh (1987), 30 nohut hattında tane verimi ve verim bileşenleri arasındaki ilişkileri incelemiş; tane veriminin bitkide bakla sayısı ile olumlu ve önemli ilişkilerinin olduğunu belirlemişler, bitkide bakla sayısına göre yapılacak seleksiyonun etkili olacağını belirtmişleridir (Saxena, 1980; Slim, 1993).

İki y1llık birleştirilmiş ortalamalara göre, çiçeklenme gün sayısı, ilk bakla yüksekliği, 100 tane ağırlığı ve tane verimi değerleri bakımından çeşitler arasında istatistiki düzeyde önemli farklılıklar olduğu belirlenmiştir (Tablo 2). Projede yer alan nohut hat ve çeșitlerinin çiçeklenme gün sayısı değerlerinin 83.83-87.50 gün, bakla bağlama gün sayısı değerlerinin 63.380.0 gün, ilk bakla yüksekliği değerlerinin 19.99-31.37 cm, bitki boyu değerlerinin 59.7$81.9 \mathrm{~cm}$ arasında değişim gösterdiği saptanmıştır. Nohut hat ve çeşitlerinin iki yıllık ortalama 100 tane ağırlığı değerlerinin 34.38$47.95 \mathrm{~g}$ arasında değişim gösterdiği saptanmıştır. En düşük 100 tane ağırlığ değeri 2015 yılı yeiștirme sezounda $32.8 \mathrm{~g}$ ile EN 1823 nohut hattından, en yüksek değer ise 2014 yetiştirme sezonunda 50.2 g ile FLIP 01-24C nohut hattından elde edilmiștir. 2014 y1l yetiștirme sezonunda, FLIP 05-170C, FLIP 01-24C, EN 1683, EN 1750, EN 1751 nohut hatlar1 ve Hasanbey çeşidinin, 2015 yetiştirme sezonunda FLIP 01-24C, EN 1750, EN 1751, ÜNHB-201052, EN 1788 nohut hatlarının ve Seçkin çeşidinin, iki yıl ortalama verilerine göre FLIP 05-170C, FLIP 01-24C, EN 1683, EN 1751, EN 1685-1 nohut hatları ve Hasanbey çeşidinin 40 


\section{Doğu Akdeniz Bölgesinde İleri Çıkmış Nohut (Cicer arietinum L.) Hatlarında Kışlık Ekimde Verim ve Kalite Özelliklerinin Değerlendirilmesi}

g'ın üzerinde tane iriliğine sahip oldukları saptanmıştır. Biçer ve Şakar (2003), 2002 ilkbahar yetiștirme mevsiminde Diyarbakır ekolojik koşullarında bazı nohut hat ve çeşitlerin tarımsal karakterlerin belirlenmesi ve karakterler arası ilişkilerin tespiti amacıyla yürüttükleri çalışmada çeşit ve hatlar arasında bitki boyu, 100 tane ağırlı̆̆ 1 ve birim alan tane verimi bakımından farklılıkların istatistiksel olarak önemli olduklarını tespit etmişlerdir.

Nohut hat ve çeşitlerinin 2014 y1lı yetiştirme sezonunda en düşük değer $102,2 \mathrm{~kg} / \mathrm{da}$ ile EN 1823 nohut hattından, en yüksek değer ise $353,7 \mathrm{~kg} / \mathrm{da}$ ile İnci çeşidinden elde edilmiştir. 2015 y1lı yeiştirme sezounda en düşük değer $43.4 \mathrm{~kg} / \mathrm{da}$ ile ÜNHB-2010-97 nohut hattından, en yüksek değer ise yine $405.4 \mathrm{~kg} / \mathrm{da}$ ile İnci çeşidinden elde edilmiştir. İki yıllık ortalama tane verimi değerlerinin 98.15-379.56 kg/da arasında değişim gösterdiği saptanmıştır. 2014 yılı yetiştirme sezonunda, FLIP 05-150C, FLIP 05-170C, FLIP 01-24C, EN 1683, EN 1750 nohut hatları, Hasanbey ve İnci çeşitlerinin, 2015 yetiştirme sezonunda Hasanbey, Seçkin ve İnci çeșitlerinin, iki yıl ortalama verilerine göre FLIP 05-150C, FLIP 01-24C, EN 1788 nohut hatları ve Hasanbey, Seçkin ve İnci çeşitlerinin $200 \mathrm{~kg} / \mathrm{da}$ 'ın üzerinde tane verimine sahip oldukları saptanmıştır. Erdemci ve ark. (2016), 2011 ve 2012 yıllarında Diyarbakır ekolojik koşullarında kışlık olarak yetiştirilen farklı nohut genotiplerinde tane verimi ile yüz tane ağırlığ arasında olumsuz ve önemli $(\mathrm{p}<0.05)$ ilişki; bitki boyu, bitkide ana dal sayıs1, bitkide dolu bakla sayıs1 ve bitkide tane sayısı aras1 arasında ise olumlu ve önemli $(p<0.01)$ ilişkiler bulunduğu tespit etmiştir. Anlarsal ve ark. (1999), Çukurova koşullarında iki yıl süreyle kışlık olarak yetiştirdikleri 23 hattan oluşan nohut populasyonunda bitki boyunda 67.9-84.2 $\mathrm{cm}$, bitkide bakla sayısında 15.8-27.3 adet, bitkide tane sayısinda 17.0-28.8 adet, 100 tane ağırlığında $26.7-37.5 \mathrm{~g}$, hasat indeksinde \%28.37-34.93, bitki tane veriminde 5.3-8.6 g ve tane veriminde de $178.6-271.9 \mathrm{~kg} / \mathrm{da}$ arasinda değişen değerler elde etmişlerdir.

Ascocyhta yanıklığı hastalığı bakımından (Tablo 2) birinci yılda yoğun görülmemesi nedeniyle olumsuz bir etki gözlenmemiştir. Fakat ikinci y1lda nohut hat ve çeşitleri değerlendirildiğinde yağış miktarının daha fazla olması ve özellikler çiçeklenme dönemine denk gelmesi nohut genotiplerinde antaknoz yanıklığı hastalığının orta ve şiddetli düzeyde görülmesine yol açmıştır. Ascochyta yanıklığı hastalığının yoğunluğuna bağlı olarak hat ve çeşitlerin 100 tane ağırlığı değerleri ve tane verimlerinde önemli azalmalar yaşanmıştır. Wenhua Du ve ark. (2012), nohuttaki yanıklık etmeni ile ilgili çalışmalar yapmışlardır. Yapılan çalışmalar ile dünya çapında ve Avusturalya'daki nohutlarda Ascochyta yanıklık etmeninin Ascochyta rabiei olduğunu açıklamışlardır. Leo ve ark. (2016), Avustralya'da nohuta etki eden çok sayıdaki Ascochyta rabiei patotipinin, nohutta 1slah çalışmalarını ciddi şekilde engellediğini ileri sürmüşlerdir. Sürekli dayanıklılık için yetiştirmenin, farklı şiddete sahip izolatlara karş1 savunma yanıtlarının detaylı bilgisi ile desteklendiği sürece faydalı olacağını belirtmişlerdir (Tripathi, 1985).

\section{Nohut Genotipleri Kalite Değerleri}

Doğu Akdeniz Tarımsal Araştırma Enstitüsünde daha önce yapılan 1slah çalışmalarda öne çıkmış toplam 17 hat ile 3 kontrol nohut hat ve çeşitleri verim denemesinde kalite analizleri için tekerrürler birleştirilerek iyice harman yapılıp örnekler alınmıştır. Nohut ileri hatlar verim denemesine ait kalite sonuçları ortalama değerleri Tablo3'de verilmiştir.

Adana ileri hatları verim denemesi 2014 yıl1 yetiştirme sezonunda Tablo 3'den görüleceği üzere kalite değerleri bakımından en düşük ve en yüksek kuru ağırlık değerleri 41,58-55,06g; yaş ağırlık değerleri 79,30-109,73g; su alma kapasitesi $0,38-0,53 \mathrm{~g} /$ tane; su alma indeksi \%0,91-1,09; kuru hacim değerleri 83-92ml; yaş hacim değerleri $170-194 \mathrm{ml}$; şişme kapasitesi $0,37-0,54 \mathrm{ml} /$ tane; şişme indeksi $\% 2,12-2,46$ değerleri arasında değişim gösterdikleri tespit edilmiştir.

Atmaca (2008), doktora çalışmasında ekim tarihi geciktikçe kuru hacim ortalamalarının azaldığ 1 tespit edilmiştir. 


\section{Doğu Akdeniz Bölgesinde İleri Çıkmış Nohut (Cicer arietinum L.) Hatlarında Kışlık Ekimde Verim ve Kalite Özelliklerinin}

Değerlendirilmesi

Çizelge 2. Doğu Akdeniz Bölgesi İleri Çıkmış Hatlar Verim ve Morfolojik Özellik Değerleri (2014-2015)

\begin{tabular}{|c|c|c|c|c|c|c|c|c|c|c|c|c|c|c|c|c|c|c|c|c|c|}
\hline \multirow[t]{2}{*}{$\begin{array}{l}\text { Sira } \\
\text { No }\end{array}$} & \multirow[t]{2}{*}{ Çeşitler } & \multicolumn{3}{|c|}{$\begin{array}{l}\text { Çiçeklenme Gün Sayısı } \\
\text { (Gün) }\end{array}$} & \multicolumn{2}{|c|}{$\begin{array}{l}\text { Ascochyta } \\
(1-9)\end{array}$} & \multicolumn{3}{|c|}{$\begin{array}{l}\text { Bakla Bağlama Gün } \\
\text { Sayıs1 (Gün) }\end{array}$} & \multicolumn{3}{|c|}{$\begin{array}{l}\text { İlk Bakla Yüksekliği } \\
(\mathrm{Cm})\end{array}$} & \multicolumn{3}{|c|}{ Bitki Boyu (Cm) } & \multicolumn{3}{|c|}{100 Tane Ağırlığı $(\mathrm{G})$} & \multicolumn{3}{|c|}{ Tane Verimi (Kg/Da) } \\
\hline & & 2014 & 2015 & ort. & 2014 & 2015 & 2014 & 2015 & ort. & 2014 & 2015 & ort. & 2014 & 2015 & ort. & 2014 & 2015 & ort. & 2014 & 2015 & ort. \\
\hline 1 & FLIP 05-150 C & $61,6 \mathrm{AB}$ & 110,3 & $86 \mathrm{~A}$ & $1-2$ & 4 & 73,3 & 129,0 & $\begin{array}{c}101,17 \mathrm{~A} \\
\mathrm{~B}\end{array}$ & $23,8 \mathrm{AB}$ & 36,6A-C & $30,26 \mathrm{AB}$ & 78,3 & 78,3 & 78,3 & $39,9 \mathrm{AB}$ & $37,4 \mathrm{AB}$ & $38,68 \mathrm{~A}-\mathrm{C}$ & $259,8 \mathrm{AC}$ & $188,9 \mathrm{~B}-\mathrm{D}$ & 224,41B-D \\
\hline 2 & FLIP 05-170 C & $61,3 \mathrm{AB}$ & 111,0 & $86,17 \mathrm{~A}$ & $1-2$ & 7 & 73,3 & 130,3 & \begin{tabular}{|c|}
$101,83 \mathrm{~A}$ \\
$\mathrm{~B}$ \\
\end{tabular} & $21,1 \mathrm{AB}$ & $26,1 \mathrm{~A}-\mathrm{C}$ & \begin{tabular}{|c|}
$23,61 \mathrm{AB}$ \\
$\mathrm{C}$
\end{tabular} & 73,8 & 66,6 & 70,3 & $43,4 \mathrm{AB}$ & $39,3 \mathrm{AB}$ & $41,35 \mathrm{~A}-\mathrm{C}$ & $211,2 \mathrm{AC}$ & $85,1 \mathrm{CD}$ & 148,19C-E \\
\hline 3 & $\begin{array}{l}\text { FLIP 01-24 C } \\
\end{array}$ & $59,0 \mathrm{~B}$ & 109,3 & $84,17 \mathrm{~A}$ & $1-3$ & 5 & 74,0 & 126,0 & $100 \mathrm{AB}$ & $18,3 \mathrm{~B}$ & $31,6 \mathrm{~A}-\mathrm{C}$ & $\begin{array}{c}24,98 \mathrm{AB} \\
\mathrm{C}\end{array}$ & 78,8 & 69,9 & 74,4 & $50,2 \mathrm{~A}$ & $45,7 \mathrm{~A}$ & $47,95 \mathrm{~A}$ & $295,4 \mathrm{AC}$ & $172,7 \mathrm{CD}$ & 234,07B-D \\
\hline 4 & $\mathrm{E}$ & $61,6 \mathrm{AB}$ & 112,0 & $86,83 \mathrm{~A}$ & $1-3$ & 7 & 74,0 & 130,7 & $\begin{array}{c}102,33 \mathrm{~A} \\
\mathrm{~B}\end{array}$ & $20,5 \mathrm{AB}$ & $26,7 \mathrm{~A}-\mathrm{C}$ & $\begin{array}{c}23,61 \mathrm{AB} \\
\mathrm{C}\end{array}$ & 82,7 & 65,5 & 74,1 & $41,6 \mathrm{AB}$ & $39,7 \mathrm{AB}$ & $40,65 \mathrm{~A}-\mathrm{C}$ & $231 \mathrm{AC}$ & $79,9 \mathrm{CD}$ & 155,44B-E \\
\hline 5 & EN 1 & $61,6 \mathrm{AB}$ & 110,7 & 86,17 & $1-3$ & 6 & 74,0 & 128,7 & \begin{tabular}{|c|}
$101,33 \mathrm{~A}$ \\
$\mathrm{~B}$ \\
\end{tabular} & $22,7 \mathrm{AB}$ & $25,5 \mathrm{~A}-\mathrm{C}$ & \begin{tabular}{|c|}
$23,88 \mathrm{AB}$ \\
$\mathrm{C}$
\end{tabular} & 84,7 & 61,6 & 74,7 & $39,2 \mathrm{AB}$ & $39,1 \mathrm{AB}$ & $38,34 \mathrm{~A}-\mathrm{C}$ & $175,5 \mathrm{BC}$ & $133,2 \mathrm{CD}$ & 152,41C-E \\
\hline 6 & EN 1750 & $61,6 \mathrm{AB}$ & 110,7 & $86,17 \mathrm{~A}$ & $1-3$ & 7 & 74, & 128,7 & $\begin{array}{c}101,33 \mathrm{~A} \\
\mathrm{~B}\end{array}$ & $24,4 \mathrm{AB}$ & $25,5 \mathrm{~A}-\mathrm{C}$ & $\begin{array}{c}24,97 \mathrm{AB} \\
\mathrm{C}\end{array}$ & 76,1 & $\mid 69,9$ & 73,0 & $43,3 \mathrm{AB}$ & $40,3 \mathrm{AB}$ & $41,80 \mathrm{~A}-\mathrm{C}$ & $221,4 \mathrm{AC}$ & $52,2 \mathrm{D}$ & 136,81DE \\
\hline 7 & $\mathrm{E}$ & $60,6 \mathrm{AB}$ & 110,7 & $85,67 \mathrm{~A}$ & $1-3$ & 7 & 73,3 & 129,0 & $\begin{array}{c}101,17 \mathrm{~A} \\
\mathrm{~B}\end{array}$ & $19,4 \mathrm{AB}$ & $20,5 \mathrm{C}$ & $19,99 \mathrm{C}$ & 69,4 & 49,9 & 59,7 & $2 \mathrm{AB}$ & $45,4 \mathrm{AB}$ & $46,34 \mathrm{~A}$ & $272,1 \mathrm{AC}$ & $76,4 \mathrm{CD}$ & 174,30B-E \\
\hline 8 & EN 1 & $61,66 \mathrm{AB}$ & 113,3 & $87,5 \mathrm{~A}$ & $1-4$ & 6 & 74,0 & 132,0 & $103 \mathrm{~A}$ & $23,33 \mathrm{AB}$ & $25,5 \mathrm{~A}-\mathrm{C}$ & $\begin{array}{c}24,42 \mathrm{AB} \\
\mathrm{C}\end{array}$ & 81,7 & 61,6 & 71,6 & $40,89 \mathrm{AB}$ & $37,9 \mathrm{AB}$ & $39,39 \mathrm{~A}-\mathrm{C}$ & $179,55 \mathrm{AC}$ & $137,6 \mathrm{CD}$ & 143,30C-E \\
\hline 9 & $\begin{array}{l}\text { ÜNHB- } \\
52 \\
\end{array}$ & $62,3 \mathrm{AB}$ & 112,3 & 87,33 & $1-$ & 6 & 74,6 & 131,3 & $103 \mathrm{~A}$ & $24,4 \mathrm{AB}$ & 27,7A-C & $\begin{array}{c}26,09 \mathrm{AB} \\
\mathrm{C}\end{array}$ & 95,5 & 56,1 & 75,8 &, $7 \mathrm{AB}$ & $43,2 \mathrm{AB}$ & $43,97 \mathrm{~A}-\mathrm{C}$ & $225,5 \mathrm{AC}$ & $137,6 \mathrm{CD}$ & 181,59B-E \\
\hline 10 & $\begin{array}{l}\text { ÜNHB-2010- } \\
95\end{array}$ & $0 \mathrm{AB}$ & 112,0 & $86,5 \mathrm{~A}$ & $1-3$ & 7 & 74,6 & 130,7 & $102,67 \mathrm{~A}$ & 7,2 A & $31,1 \mathrm{~A}-\mathrm{C}$ & $29,14 \mathrm{AB}$ & 89,5 & 69,4 & 79,5 & $6 \mathrm{AB}$ &, $7 \mathrm{AB}$ & $38,68 \mathrm{~A}-\mathrm{C}$ & $151,6 \mathrm{BC}$ &, $0 \mathrm{CD}$ & $116,85 \mathrm{DE}$ \\
\hline 11 & $\begin{array}{l}\text { ÜNHB-2010- } \\
96\end{array}$ & $60,6 \mathrm{AB}$ & 113,0 & $86,83 \mathrm{~A}$ & $2-3$ & 7 & 7,0 & 132,0 & $103 \mathrm{~A}$ & $25 \mathrm{AB}$ & $22,7 \mathrm{~A}-\mathrm{C}$ & $\begin{array}{c}23,88 \mathrm{AB} \\
\mathrm{C}\end{array}$ & 81,1 & 58,3 & 69,7 & $41,9 \mathrm{AB}$ & $39,0 \mathrm{AB}$ & $40,52 \mathrm{~A}-\mathrm{C}$ & $168,5 \mathrm{AC}$ & $98,7 \mathrm{CD}$ & 133,63DE \\
\hline 12 & $\begin{array}{l}\text { ÜNHB-2010- } \\
97 \\
\end{array}$ & $60,6 \mathrm{AB}$ & 113,7 & $87,17 \mathrm{~A}$ & $3-2$ & 7 & 74,6 & 132,3 & $103,5 \mathrm{~A}$ & $21,6 \mathrm{AB}$ & 23,9A-C & \begin{tabular}{|c|}
$\begin{array}{c}22,77 \mathrm{AB} \\
\mathrm{C}\end{array}$ \\
\end{tabular} & 87,2 & 67, & 77,2 & $36,4 \mathrm{AB}$ & $36,0 \mathrm{AB}$ & $3 \mathrm{C}$ & BC & $4 \mathrm{D}$ & $8,15 \mathrm{E}$ \\
\hline 13 & EN 178 & $58,6 \mathrm{~B}$ & 111,7 & $85,17 \mathrm{~A}$ & 3-3 & 5 & 73,3 & 130,0 & $\begin{array}{c}101,67 \mathrm{~A} \\
\mathrm{~B}\end{array}$ & $21,6 \mathrm{AB}$ & $23,0 \mathrm{~A}-\mathrm{C}$ & $22,33 \mathrm{BC}$ & 73,3 & 59,4 & 66,4 & $39,3 \mathrm{AB}$ & $43,4 \mathrm{AB}$ & $41,35 \mathrm{~A}-\mathrm{C}$ & $202,5 \mathrm{AC}$ & 198,5B-D & 200,51B-E \\
\hline 14 & \begin{tabular}{|l|l} 
EN 1800 \\
\end{tabular} & $63,3 \mathrm{AB}$ & 110,0 & $86,67 \mathrm{~A}$ & $1-2$ & 6 & 75,3 & 129,0 & \begin{tabular}{|c|}
$102,17 \mathrm{~A}$ \\
$\mathrm{~B}$ \\
\end{tabular} & $26,1 \mathrm{AB}$ & $26,1 \mathrm{~A}-\mathrm{C}$ & \begin{tabular}{|c|}
$26,09 \mathrm{AB}$ \\
$\mathrm{C}$
\end{tabular} & 91,6 & 72,2 & 81,9 & $45,2 \mathrm{AB}$ & $45,5 \mathrm{AB}$ & $45,36 \mathrm{AB}$ & $245,1 \mathrm{AC}$ & $127,2 \mathrm{CD}$ & 186,18B-E \\
\hline 15 & EN 18 & $60,6 \mathrm{AB}$ & 111,0 & $85,83 \mathrm{~A}$ & $1-2$ & 7 & 74,6 & 130,0 & \begin{tabular}{|c|}
$102,33 \mathrm{~A}$ \\
$\mathrm{~B}$ \\
\end{tabular} & $25,5 \mathrm{AB}$ & $21,6 \mathrm{BC}$ & \begin{tabular}{|c|}
$23,59 \mathrm{AB}$ \\
$\mathrm{C}$ \\
\end{tabular} & 72,7 & 55,5 & 64,2 &, $7 \mathrm{AB}$ & $42,0 \mathrm{AB}$ & $42,40 \mathrm{~A}-\mathrm{C}$ & $63,7 \mathrm{AC}$ & 3,5CD & 181,11B-E \\
\hline 16 & $\mathrm{E}$ & $61,0 \mathrm{AB}$ & 112,7 & $86,83 \mathrm{~A}$ & $2-2$ & 6 & 74,6 & 132,0 & $103,33 \mathrm{~A}$ & $21,1 \mathrm{AB}$ & $30,0 \mathrm{~A}-\mathrm{C}$ & $\begin{array}{c}25,55 \mathrm{AB} \\
\mathrm{C}\end{array}$ & 82,7 & 76,6 & 79,7 & $36,0 \mathrm{AB}$ & $32,8 \mathrm{~B}$ & $34,4 \mathrm{C}$ & $102,2 \mathrm{C}$ & $135,1 \mathrm{CD}$ & $118,67 \mathrm{DE}$ \\
\hline 17 & EN 1830 & $59,6 \mathrm{AB}$ & 111,3 & $85,5 \mathrm{~A}$ & $1-2$ & 5 & 74,0 & 130,0 & $102 \mathrm{AB}$ & $24,4 \mathrm{AB}$ & $26,6 \mathrm{~A}-\mathrm{C}$ & $\begin{array}{c}25,55 \mathrm{AB} \\
\mathrm{C}\end{array}$ & 81,1 & 64,4 & 72,8 & $39,1 \mathrm{AB}$ & $37,5 \mathrm{AB}$ & $38,31 \mathrm{~A}-\mathrm{C}$ & $140,4 \mathrm{BC}$ & $152,4 \mathrm{CD}$ & 146,41C-E \\
\hline 18 & $\mathrm{H} t$ & $58,6 \mathrm{~B}$ & 109,0 & $83,83 \mathrm{~A}$ & $1-3$ & 4 & 63,3 & \begin{tabular}{|l|}
125,7 \\
\end{tabular} & \begin{tabular}{|c|}
$94,5 \mathrm{~B}$ \\
\end{tabular} & $23,3 \mathrm{AB}$ & $39,4 \mathrm{~A}$ & $31,37 \mathrm{~A}$ & \begin{tabular}{|l|l|}
82,7 \\
\end{tabular} & 72,2 & \begin{tabular}{|l|}
77,5 \\
\end{tabular} & $46,5 \mathrm{AB}$ & $39,8 \mathrm{AB}$ & $43,18 \mathrm{~A}-\mathrm{C}$ & $319,3 \mathrm{AB}$ & $238,9 \mathrm{BC}$ & $279,11 \mathrm{AB}$ \\
\hline 19 & SEÇK & $64,7 \mathrm{~A}$ & 108,0 & $86,14 \mathrm{~A}$ & $1-2$ & 4 & 80,0 & 124,3 & $\begin{array}{c}101,55 \mathrm{~A} \\
\mathrm{~B}\end{array}$ & $21,5 \mathrm{AB}$ & $38,8 \mathrm{~A}$ & $30,10 \mathrm{AB}$ & 69,7 & \begin{tabular}{|l|}
68,3 \\
\end{tabular} & 71,2 & $37,1 \mathrm{AB}$ & $40,8 \mathrm{AB}$ & $8,41 \mathrm{~A}-\mathrm{C}$ & $194,6 \mathrm{AC}$ & $342,7 \mathrm{AB}$ & $270,10 \mathrm{~A}-\mathrm{C}$ \\
\hline 20 & INCI & \begin{tabular}{|c|}
$62,0 \mathrm{AB}$ \\
$* *$
\end{tabular} & 112,7 & $87,33 \mathrm{~A}$ & $1-2$ & 4 & 74,0 & \begin{tabular}{|l|}
131,7 \\
\end{tabular} & \begin{tabular}{|l|}
$102,83 \mathrm{~A}$ \\
\end{tabular} & $22,2 \mathrm{AB}$ & $38,3 \mathrm{AB}$ & $30,24 \mathrm{AB}$ & 68,3 & 0,1 &, 2 & $34,4 \mathrm{~B}$ & $34,4 \mathrm{AB}$ & $34,38 \mathrm{C}$ & $353,7 \mathrm{~A}$ & $405,4 \mathrm{~A}$ & $379,56 \mathrm{~A}$ \\
\hline & & 2,66 & \begin{tabular}{|l|} 
OD \\
1,9 \\
\end{tabular} & $\frac{\mathrm{OD}}{1,78}$ & & & $\frac{\text { ÖD }}{5,92}$ & \begin{tabular}{|l|} 
ÖD \\
2,1
\end{tabular} & $\frac{\mathrm{O} \mathrm{D}}{3,82}$ & $\frac{* * *}{10,98}$ & $\frac{* *}{19}$ & $\frac{{ }^{* * *}}{1,08}$ & \begin{tabular}{|c|} 
ÖD \\
93,01 \\
\end{tabular} & \begin{tabular}{|c|} 
ÖD \\
18,2 \\
\end{tabular} & \begin{tabular}{|c|} 
ÖD \\
8,32 \\
\end{tabular} & \begin{tabular}{|c|}
$* * *$ \\
11,96
\end{tabular} & $\begin{array}{c}* * \\
10,4\end{array}$ & 1,87 & $\begin{array}{c}* * \\
29,21\end{array}$ & $\begin{array}{c}* * * \\
36,2\end{array}$ & $\frac{* *}{106,77}$ \\
\hline TUKE &, 05 & & & & & & & & & & & & & & & & & & & & \\
\hline
\end{tabular}


Karasu (1993), değişik yörelerden temin ettiği 22 adet nohut hat ve çeşitlerinin bazı agronomik ve teknolojik karakterlerini ve bu karakterler arası ilişkileri incelemek amacı ile 1989 ile 1991 yılları arasında yapmış olduğu çalışmasında, iri taneli nohutların küçük taneli nohutlara göre su alma kapasitelerinin yüksek olduğunu ve daha uzun sürede piştiğini saptamıştır. Elek analiz değerleri ise 9 nolu elekte $\% 21,25-81,02 ; 8$ nolu elekte \%28,60-74,28; 7 nolu elekte \%1,29-10,62 değerleri arasında değişim gösterdikleri belirlenmiștir. Protein analiz değerleri ise en yüksek EN 1788 hattından \% 23,50, en düşük değer ise EN 1683 hattından \% 21,01 değerleri elde edilmiştir ve bu değerler arasında değişim gösterdikleri belirlenmiştir. Bu çalışmada En 1683 ve EN1685 hatları kuru ağırlık, yaş ağırlık, su alma kapasitesi, kuru hacim, yaş hacim, şişme kapasitesi değerleri bakımından yüksek değerleri vererek ön plana çıkmıştır (Tablo 4). Singh ve ark. (1990), ICARDA'dan temin ettikleri kabuli nohut genotiplerinde 100 tane ağırlığ1, protein miktarı ve pişme zamanı sürelerini belirlemek üzere yaptıkları araştırmada, 100 tane ağırlı̆̆ının 8 ile $67 \mathrm{~g}$, protein miktarının \%14.3 ile \%27 ve pişme süresinin 50 dakika ile 296 dakika arasında değiştiğini bildirmişlerdir. Ayrıca protein miktarının yetiştirme sezonunda meydana gelen iklim olaylarına göre değişebileceğini ifade etmişlerdir.

2015 yılı yetiştirme sezonunda (Tablo 3) görüleceği üzere kalite değerleri bakımından en yüksek ve en düşük kuru ağırlık değerleri 37,0348,44g; yaş ağırlık değerleri 71,57-101,54g; su alma kapasitesi 0,35-0,54g/tane; su alma indeksi $\% 0,93-1,13$; kuru hacim değerleri $77-87 \mathrm{ml}$; yaş hacim değerleri $162-190 \mathrm{ml}$; şișme kapasitesi 0,35-0,54-ml/tane; şişme indeksi \%2,17-2,52 değerleri arasında değişim gösterdikleri tespit edilmiștir. Elek analiz değerleri ise 9 nolu elekte $\% 10,84-72,60 ; 8$ nolu elekte \%26,28-80,17; 7 nolu elekte \%1,19-14,18 değerleri arasında değişim gösterdikleri belirlenmiştir. Protein analiz değerleri ise en yüksek değer EN 1788 çeşitinden $\% 20,59$, en düşük değer İnci çeşitinden $\% 18,26$ değerleri elde edilmiş olup ve bu değerler arasında değişim gösterdikleri belirlenmiştir. Adana lokasyonunda ileri çıkmış hatlar denemesinde yer alan çeşitler arasında EN
1685 çeşidi yaş ağırlık, su alma indeksi, yaş hacim, şişme kapasitesi bakımından diğer çeșitlere göre en yüksek değerleri vererek ön plana çıkmıştır. Köksal ve ark. (1993), ülkemizin farklı bölgelerinde yetiştirilen nohut genotiplerinin teknolojik kalitesi üzerine çevrenin etkilerini belirlemek amacı ile yaptıkları araştırmada; genotip ve çevrenin, kuru ve yaş ağırlık, kuru ve yaş hacim ile şişme indeksi değerlerini önemli düzeyde etkilediğini, kuru pişme süresi, yaş pişme süresi ve protein miktarının ise sadece çevreden önemli düzeyde etkilendiğini bildirmişlerdir. 2014 ve 2015 y1lı yetiştirme sezonlarında Tablo3-4 görüleceği üzere nohut ileri hatlar verim denemesi ortalama kalite değerleri bakımından en düşük ve en yüksek kuru ağırlık değerleri 39,31-50,55g; yaş ağırlık değerleri 71,57-101,54g; su alma kapasitesi 0,37-0,52g/tane; su alma indeksi $\% 0,92-1,11$; kuru hacim değerleri 80,00-8,50ml; yaş hacim değerleri 166,00-190,50ml; şişme kapasitesi 0,36-0,53ml/tane, şişme indeksi \%2,21-2,48 değerleri arasında değişim gösterdikleri tespit edilmiştir. Adana lokasyonu nohut ileri hatlar verim denemesinde her iki yetiștirme sezonu bakımından ortalama elek analiz değerleri incelendiğinde ise 9 nolu elekte $\% 16,05-72,11 ; 8$ nolu elekte $\% 27,44-77,23 ; 7$ nolu elekte ise \%1,19-12,39 değerleri arasında değişim gösterdikleri belirlenmiştir. Her iki yetiştirme sezonu bakımından ortalama protein analiz değerleri ise en yüksek EN 1788 çeşidinden $\% 22,04$, en düşük değer ise İnci çeşidinden \%19,74 değerleri elde edilmiştir. Adana lokasyonunda, Adana ileri hatlar denemesinde yer alan çeşitler arasında EN 1683, FLIP 01-24C, EN 1800 hatlanı diğer çeşitlere göre kalite değerlerinin yüksekliği ile ön plana çıkmıșlardır. 
Doğu Akdeniz Bölgesinde İleri Çıkmış Nohut (Cicer arietinum L.) Hatlarında Kışılk Ekimde Verim ve Kalite Özelliklerinin Değerlendirilmesi

Çizelge 3. Doğu Akdeniz Bölgesi İleri Çıkmış Hatlar Kalite Özellik Değerleri (2014-2015)

\begin{tabular}{|c|c|c|c|c|c|c|c|c|c|c|c|c|c|c|c|c|c|c|c|c|c|c|c|c|c|}
\hline \multirow[t]{2}{*}{ No } & \multirow[t]{2}{*}{ Çeşitler } & \multicolumn{3}{|c|}{$\begin{array}{c}\text { Kuru Ağırlık } \\
\text { (100 Tane } \\
\text { A ğırlığı) (G) }\end{array}$} & \multicolumn{3}{|c|}{ Yaş Ağırlık(G) } & \multicolumn{3}{|c|}{$\begin{array}{c}\text { Su Alma } \\
\text { Kapasitesi } \\
\text { (g/tane) }\end{array}$} & \multicolumn{3}{|c|}{$\begin{array}{l}\text { Su Alma İndeksi } \\
(\%)\end{array}$} & \multicolumn{3}{|c|}{$\begin{array}{l}\text { Kuru Hacim } \\
\text { (Ml) }\end{array}$} & \multicolumn{3}{|c|}{ Yaş Hacim (Ml) } & \multicolumn{3}{|c|}{$\begin{array}{c}\text { Şişme } \\
\text { Kapasitesi } \\
\text { (ml/Tane) }\end{array}$} & \multicolumn{3}{|c|}{$\begin{array}{l}\text { Şişme İndeksi } \\
(\%)\end{array}$} \\
\hline & & 2014 & 2015 & ort & 2014 & 2015 & ort & 2014 & 2015 & ort & 2014 & 2015 & ort & \begin{tabular}{|c|}
201 \\
4 \\
\end{tabular} & $\begin{array}{c}201 \\
5 \\
\end{array}$ & ort & 2014 & 2015 & ort & 2014 & \begin{tabular}{|c|}
201 \\
5
\end{tabular} & ort & 2014 & 2015 & ort \\
\hline 1 & $\begin{array}{l}\text { Flip 05-150 } \\
\text { C }\end{array}$ & 0,32 & 4,23 & 47,28 & 00,64 & 92,03 & 96,34 & 0,50 & 0,48 &, 49 & 1,00 & 108 & 1,04 & 88 & 85 & 86, & 190 & 182 & 186,00 & 0,52 & 0,47 & 0,50 & 2,37 & 2,34 & 2,36 \\
\hline 2 & $\begin{array}{l}\text { Flip 05-170 } \\
\text { C }\end{array}$ & 9,68 & 0,81 & 45,25 & 00,98 & 86,79 & 93,89 & 0,51 & 0,46 & 0,49 & 1,03 & 1,13 & 1,08 & 88 & 82 & 85,0 & 190 & 176 & 183,00 & 0,52 & 0,44 & 0,48 & 2,37 & 2,38 & 2,38 \\
\hline 3 & $\begin{array}{l}\text { Flıp 01-24 } \\
\text { C }\end{array}$ & 2,54 & 3,44 & 50,49 & 284 & 724 & 0 & 0 & 0 & 0,5 & 0 & 1,01 & 0,9 & 90 & 87 & 88 & 190 & 1 & 0 & 0,5 & 0,51 & 0,51 & 2,25 & 2,38 & 2,32 \\
\hline 4 & En 1683 & 22 & 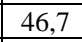 & 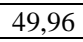 & 39 & 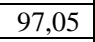 & 2 & 0,53 & & & & & & & & & 194 & & & 53 & 0,51 & 0,52 & 29 & 12 & 2,36 \\
\hline 5 & $\mathrm{E}$ & 00 &, 67 & 4 & & 54 & & & & & & & & & & & 86 & & & 0,51 & 0,54 & 0,53 & 2,46 & & 2,48 \\
\hline 6 & En 1 & 69 & 5,47 & 5,58 &, 79 & 4,24 & 9 & & & & & 1, & & & & & 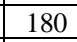 & & & 0,46 & 0,48 & 0,47 & 2,35 & & 2,34 \\
\hline 7 & $\mathrm{E}$ & 80 & 7,04 & 9,92 & 4,25 & 4 & 9 & & & & & & & & & & 194 & & & 0,54 & 0,47 & 0,51 & 2,35 & & 2,33 \\
\hline 8 & En 1 & 39 & 53 & 148 & & & & & & & & & & & & & & & & 0,52 & 0,44 & 48 & 14 & & 2,43 \\
\hline 9 & $\begin{array}{l}\text { Ünhb-2010- } \\
52\end{array}$ &, 06 &, 55 & 47,31 & 7,53 & 37 & 93,45 & 0,52 & 0,40 & 46 & 0,95 & 1,01 & 0,98 & 92 & 8 & 86 & 194 & 170 & 00 & 0,52 & 0,39 & 0,46 & 2,24 & 2,26 & 2,25 \\
\hline 10 & $\begin{array}{l}\text { Ünhb-2010- } \\
95\end{array}$ & 1,40 &, 67 & 46,54 & 4,02 & , &, 9 & 0 & 0 & 0,50 & 1 & 1,11 & 1,07 & 8 & 8 & 85 & 193 & 1 & 0 & 0,54 & 0,47 & 0,51 & 2,38 & 2,52 & 2,45 \\
\hline 11 & $\begin{array}{l}\text { Ünhb-2010- } \\
96\end{array}$ & 7,36 & 3,93 & 45,65 & 785 & 6 & 9377 & 0,5 & 0 & 0,48 & 107 & 1,04 & 1,0 & 86 & 84 & 85, & 188 & 180 & 184,00 & 0,52 & 0,46 & 0,49 & 2,44 & 2,35 & 2,40 \\
\hline 12 & $\begin{array}{l}\text { Ünhb-2010- } \\
97\end{array}$ & 45,00 & 38,58 & 41,79 & 92,42 & 80,93 & 86,68 & 0,47 & 0,42 & 0,45 & 1,05 & 1,10 & 1,08 & 84 & 80 & 82,0 & 182 & 172 & 177,00 & 0,48 & 0,42 & 0,45 & 2,41 & 2,40 & 2,41 \\
\hline 13 & F & 20 & 59 & 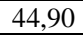 & 77 & 63 & 93,70 & 0,51 & 0,47 & 0,49 & 1,12 & 105 & 109 & 85 & 84 & 845 & 18 & 180 & 182,00 & 49 & 0,46 & 0,48 & 2,40 & 35 & 2,38 \\
\hline 14 & $\mathrm{E}$ & ,91 &, 19 &, 55 & 6,15 & 3,62 & 99,8 & & & & & & 0 , & & & & 19 & 18 & 188,50 & 0,53 & 0,47 & 0,50 & 2,29 & & 2,30 \\
\hline 15 & En 1 &, 39 & 5,32 &, 36 & 3,97 & 91,16 & 97,5 & & & & 0,98 & 0, & 0, & 9 & & 88 & 192 & 18 & 00 & 0,51 & 0,49 & 0,50 & 2,24 & 0 & 2,32 \\
\hline 16 & En 1 &, 57 & 41,76 & 47,17 & 109,73 & 678 & 98,2 & & & & 1,09 & 4 & 1, & 8 & & & 188 & 17 & 182,00 & 0,52 & 0,41 & 0,47 & 2,44 & 2,17 & 2,31 \\
\hline 17 & En 1 & 5,87 & 44,03 & 45, & & 90, & 9 & & & & & & & 86 & & & 18 & 180 & & 0,5 & 0,46 & 0,48 & 2,39 & 2,35 & 2,37 \\
\hline 18 & Hasanbey & 47,79 & 43,2 & 45,50 & 93,43 & 85,79 & 89,61 & 0,46 & & 0 & 0,96 & 0,99 & 0,98 & \begin{tabular}{|l|}
86 \\
\end{tabular} & 83 & 5 & 182 & 176 & 179,00 & 0,46 & 0,43 & 0,45 & 2,28 & 2,30 & 2,29 \\
\hline 19 & Seçkin & 42,99 & 41,83 & 42,41 & 89,80 & 84,36 & 87,08 & & & & 1,09 & 1,0 & 10 & 83 & 82 & 82 & 180 & 174 & 177,00 & 0,47 & 0,42 & 0,45 & $2,42 \mid$ & 2,31 & 2,37 \\
\hline 20 & İnci & 41,58 & 37,03 & 39,31 & 79,30 & 71,57 & 75,44 & 0,38 & 0,35 & 0,37 & 0,91 & 0,93 & 0,92 & 83 & 77 & 80,0 & 170 & 162 & 166,00 & 0,37 & 0,35 & 0,36 & 2,12 & 2,30 & 2,21 \\
\hline
\end{tabular}


Çizelge 4. Doğu Akdeniz Bölgesi İleri Çıkmıș Hatlar Kalite Özellik Değerleri ve Elek Değerleri (2014-2015)

\begin{tabular}{|c|c|c|c|c|c|c|c|c|c|c|c|c|c|c|c|c|c|}
\hline \multirow[t]{2}{*}{$\begin{array}{l}\text { S1ra } \\
\text { No }\end{array}$} & \multirow[t]{2}{*}{ Çeşitler } & \multicolumn{4}{|c|}{2014 Elek Değerleri (\%) } & \multicolumn{3}{|c|}{2015 Elek Değerleri (\%) } & \multicolumn{3}{|c|}{$\begin{array}{l}\text { 2014-2015 Ortalama Elek } \\
\text { Değerleri }(\%)\end{array}$} & \multicolumn{3}{|c|}{ Nitrojen (\%) } & \multicolumn{3}{|c|}{ Protein $(\%)$} \\
\hline & & $9 \mathrm{~mm}$ & $8 \mathrm{~mm}$ & $7 \mathrm{~mm}$ & $6 \mathrm{~mm}$ & $9 \mathrm{~mm}$ & $8 \mathrm{~mm}$ & $7 \mathrm{~mm}$ & $9 \mathrm{~mm}$ & $8 \mathrm{~mm}$ & $7 \mathrm{~mm}$ & 2014 & $\begin{array}{l}201 \\
5\end{array}$ & Ort & 2014 & 2015 & Ort \\
\hline 1 & Flıp 05-150 C & 53,71 & 43,68 & 3,38 & 0 & 34,27 & 57,51 & 8,34 & 43,99 & 50,60 & 5,86 & 3,5579 & 3,07 & 3,31 & 22,2369 & 19,17 & 20,70 \\
\hline 2 & FLIP $05-170 \mathrm{c}$ & 60,36 & 37,71 & 1,93 & 0 & 34,48 & 54,85 & 10,72 & 47,42 & 46,28 & 6,33 & 3,5666 & 3,00 & 3,28 & 22,2913 & 18,73 & 20,51 \\
\hline 3 & FLIP 01-24 c & 71,62 & 28,60 & & 0 & 72,6 & 26,28 & 1,19 & 72,11 & 27,44 & 1,19 & 3,6262 & 3,03 & 3,33 & 22,6638 & 18,95 & 20,81 \\
\hline 4 & EN 1683 & 67,21 & 31,37 & 1,52 & 0 & 52,06 & 44,17 & 3,8 & 59,64 & 37,77 & 2,66 & 3,3610 & 3,11 & 3,24 & 21,0063 & 19,44 & 20,22 \\
\hline 5 & EN 1685 & 34,46 & 56,76 & 8,90 & 0 & 49,45 & 48,01 & 2,57 & 41,96 & 52,39 & 5,74 & 3,4415 & 3,06 & 3,25 & 21,5094 & 19,11 & 20,31 \\
\hline 6 & EN 1750 & 43,99 & 48,06 & 7,92 & 0 & 38,55 & 57,47 & 4,13 & 41,27 & 52,77 & 6,03 & 3,6194 & 3,09 & 3,35 & 22,6213 & 19,31 & 20,97 \\
\hline 7 & EN 1751 & 54,46 & 43,53 & 2,27 & 0 & 54,13 & 41,32 & 4,7 & 54,30 & 42,43 & 3,49 & 3,4110 & 3,09 & 3,25 & 21,3188 & 19,30 & 20,31 \\
\hline 8 & EN 1685-1 & 35,47 & 54,01 & 10,62 & & 22,60 & 63,42 & 14,15 & 29,04 & 58,72 & 12,39 & 3,5312 & 3,07 & 3,30 & 22,0700 & 19,17 & 20,62 \\
\hline 9 & ÜNHB-2010-52 & 81,02 & 18,01 & 1,29 & 0 & 23,98 & 61,95 & 14,18 & 52,50 & 39,98 & 7,74 & 3,4560 & 3,02 & 3,24 & 21,6000 & 18,88 & 20,24 \\
\hline 10 & ÜNHB-2010-95 & 33,97 & 55,27 & 11,05 & 0 & 13,82 & 73,98 & 12,28 & 23,90 & 64,63 & 11,67 & 3,5325 & 3,05 & 3,29 & 22,0781 & 19,09 & 20,58 \\
\hline 11 & ÜNHB-2010-96 & 45,49 & 48,58 & 6,12 & 0 & 31,12 & 63,85 & 5,06 & 38,31 & 56,22 & 5,59 & 3,5486 & 3,06 & 3,30 & 22,1788 & 19,14 & 20,66 \\
\hline 12 & ÜNHB-2010-97 & 24,64 & 71,77 & 3,85 & 0 & 21,11 & 70,49 & 8,44 & 22,88 & 71,13 & 6,15 & 3,4602 & 3,03 & 3,25 & 21,6263 & 18,95 & 20,29 \\
\hline 13 & EN 1788 & 38,68 & 56,08 & 5,28 & 0 & 40,46 & 56,60 & 2,95 & 39,57 & 56,34 & 4,12 & 3,7598 & 3,29 & 3,52 & 23,4988 & 20,59 & 22,04 \\
\hline 14 & EN 1800 & 69,48 & 28,70 & 2,11 & 0 & 71,49 & 26,3 & 2,22 & 70,49 & 27,50 & 2,17 & 3,4711 & 3,11 & 3,29 & 21,6944 & 19,41 & 20,55 \\
\hline 15 & EN 1822 & 60,03 & 38,70 & 1,28 & 0 & 26,34 & 65,09 & 8,75 & 43,19 & 51,90 & 5,02 & 3,5772 & 3,05 & 3,31 & 22,3575 & 19,04 & 20,70 \\
\hline 16 & EN 1823 & 24,00 & 63,11 & 12,48 & 0,82 & 30 & 65,23 & 4,77 & 27,00 & 64,17 & 8,63 & 3,4877 & 3,15 & 3,32 & 21,7981 & 19,66 & 20,73 \\
\hline 17 & EN 1830 & 29,64 & 61,41 & 9,16 & 0 & 37,82 & 58,11 & 4,1 & 33,73 & 59,76 & 6,63 & 3,5005 & 3,07 & 3,29 & 21,8781 & 19,20 & 20,54 \\
\hline 18 & Hasanbey & 35,77 & 62,46 & 1,96 & 0 & 35,57 & 62,27 & 2,22 & 35,67 & 62,37 & 2,09 & 3,5141 & 3,20 & 3,36 & 21,9631 & 20,00 & 20,98 \\
\hline 19 & Seçkin & 23,63 & 70,72 & 5,71 & 0 & 26,29 & 69,08 & 4,71 & 24,96 & 69,90 & 5,21 & 3,7411 & 3,26 & 3,50 & 23,3819 & 20,39 & 21,89 \\
\hline 20 & İnci & 21,25 & 74,28 & 4,71 & 0 & 10,84 & 80,17 & 9,03 & 16,05 & 77,23 & 6,87 & 3,3948 & 2,92 & 3,16 & 21,2175 & 18,26 & 19,74 \\
\hline
\end{tabular}




\section{Doğu Akdeniz Bölgesinde İleri Çıkmış Nohut (Cicer arietinum L.) Hatlarında Kışık Ekimde Verim ve Kalite Özelliklerinin Değerlendirilmesi}

\section{Sonuç}

$\mathrm{Bu}$ çalışma ile, ileri çıkmış nohut (Cicer aritinum L.) hatlarının bölgesel iklim koşullarında uyumları ve Ascochyta yanıklığına karşı tolerans/dayanıklılıkları araştırılmıştır. Adana lokasyonunda, yağış ve sıcaklık iklim koşullarının Ascocyhta yanıklığı hastalığının gelişmesine uygun olması nedeniyle doğal koşullarda yoğun görülmesi nedeniyle 100 tane ve verimler üzerinde olumsuz etkileri gözlenmiştir. $\mathrm{Bu}$ da verim kayıplarına neden olmuştur. Kontrol çeşidi olarak kullanılan tescilli bölge çeşitleri (İnci-HasanbeySeçkin) verim ve hastalık toleransları ile fark oluşturmuştur.

İki yıllık ortalamalara göre tane verimi, hastalık toleransı ve diğer özellik değerleri bakımından nohut hat ve çeşitlerinin iki y1llık ortalama tane verimi değerlerinin 98.15-379.56 kg/da arasında değişim gösterdiği saptanmıştır. Yine iki yıl ortalama verilerine göre birinci yılda FLIP 05150C, FLIP 05-170C, FLIP 01-24C, EN 1683, EN 1750, EN 1751 nohut hatları, Hasanbey ve İnci çeşitlerinin, ikinci yılda ise FLIP 05-150C, FLIP 01-24C, EN 1788 nohut hatları ve Hasanbey, Seçkin ve İnci çeşitlerinin $200 \mathrm{~kg} / \mathrm{da}$ 'ın üzerinde tane verimine sahip oldukları saptanmıştır. Ascocyhta yanıklığı hastalığ 1 bakımından (Tablo 2) birinci yılda yoğun görülmemesi nedeniyle olumsuz bir etki gözlenmemiştir. Fakat ikinci yılda nohut hat ve çeşitleri değerlendirildiğinde yağış miktarının daha fazla olması ve özellikler çiçeklenme dönemine denk gelmesi nohut genotiplerinde antaknoz yanıklığı hastalığının orta ve şiddetli düzeyde görülmesine yol açmıştır. Ascochyta yanıklığı hastalığının yoğunluğuna bağlı olarak hat ve çeşitlerin 100 tane ağırlığ değerleri ve tane verimlerinde önemli azalmalar yaşanmıştır. Kimber ve ark. (2007), nohutun epidemiyolojisiyle ilişkili $D$. rabiei üzerinde çalışmalar yapmışlardır. Hastalık etmeninin kısa mesafelerde yağmur ve rüzgâr ile yayllabildiğini belirlemişlerdir.

$\mathrm{Bu}$ denemede de kalite değerleri bakımından iki y1llık ortalama elek analiz değerleri ise 9 nolu elekte $\% 16,05-70,49 ; 8$ nolu elekte $\% 27,44-77,23$;
7 nolu elekte \%1,19-12,39 değerleri arasında değişim gösterdikleri belirlenmiştir. Protein analiz değerleri ise en yüksek EN 1788 hattından \% 22,04, en düşük İnci çeşidinden \% 19,74 değerleri elde edilmiştir ve bu değerler arasında değişim gösterdikleri belirlenmiştir. Adana lokasyonunda nohut ileri hatları denemesinde yer alan hatlar arasında EN 1683, FLIP 01-24C, EN 1685 hatlar1 kuru ağırlık, kuru hacim, yaş hacim, elek analizlerinden 9 nolu elekte diğer hatlara göre yüksek değerler vererek ön plana çıkmıştır.

Teşekkür: Bu Çalışma, TÜBiTAK 1003 Projesi, 1130070 nolu proje ile desteklenmiştir. TÜBİTAK'a katkı ve maddi desteklerinden dolayı çok teşekkür ederiz.

\section{Kaynaklar}

Anonymous, 2021. FAO. https:// www. fao. org/ faostat/

Anlarsal, A.E.,C. Yücel ve D.Özveren.1999. Çukurova koşullarında bazı nohut hatlarının verim ve verimle ilgili özelliklerinin saptanması üzerinde bir araştırma Türkiye 3.Tarla Bitkileri Kongresi Cilt III (Çayır Mera Yem Bitkileri ve Yemeklik Tane Baklagiller), s.342- 347,15-18 Kasım, Adana.

Atmaca E 2008. Eskişehir Koşullarında Bazı Nohut Çeşit Ve Hatlarında Farklı Ekim Zamanı Ve Sira Aras1 Mesafelerinin Verim, Verim Unsurları Ve Kalite Üzerine Etkisi, DoktoraTezi, 90 s.,Ankara

Azkan, N., Kaçar, O., Doğangüzel, E., Sincik, M. ve Çöplü, N. 1999. Bursa Ekolojik Koşullarında Farklı Ekim Zamanlarının Nohut Hat ve Çeşitlerinde Verim ve Verim Öğelerine Etkisi. Türkiye III. Tarla Bitkileri Kongresi, 15-18 Kasim 1999, 3; 318-323. Adana.

Bakoğlu A, 2009. Elazığ ekolojik koşullarında bazı nohut (Cicer arietinum L.) çeşitlerinin verim ve verim öğeleri üzerine bir araştırma. Harran Üniversitesi Ziraat Fakültesi Dergisi. 2009 13(1): 1-6

Biçer, B.T., Şakar, D., 2003. Bazı Nohut (Cicer arietinum L.) Köy Çeşitlerinde Bitkisel Ve 
Tarımsa Özelliklerin Belirlenmesi. Ankara Üniversitesi Ziraat Fakültesi Tarım Bilimleri Dergisi 10(4):289-396.

Erdemci, İ., Yaşar, M. Koç, M. 2016. Evaluation Of Selection Criteria İn Winter Chickpea Using Correlation Coefficient And Path Analysis. Yyü Tar. Bil. Derg. (Yyu J Agr Sc1) 2016, 26(1): 1-6

Gül, M. K., Egesel, C. Ö., Kahrıman, F., Tayyar, Ş., 2006. Çanakkale Yöresinde Nohut Bitkisinin Kışlık Olarak Yetiştirilebilme Olanakları, Uludag.Üniv.Zir.Fak.Derg.(2006) 20(1): 57-66

Karasu, A. 1993. Bazı Nohut Çeşitlerinin (CicerarietinumL.) Agronomik ve Teknolojik Karakterleri Üzerinde Bir Araştırma. Doktora Tezi (Basılmamış). Uludağ Üniversitesi, $122 \mathrm{~s}$. Bursa.

Katıyar, R.P., Singh, H.G., 1987. Interrelationships Of Physiological Attributes With Seed Yield And It's Components İn Chickpea, Farm Science Journal, 2(2),125-130.

Kimber R. B. E., Shtienberg D., Ramsey M. D., Scott E. S.,. 2007. The role of seedling infection in epiphytotics of ascochytablight on chickpea. Eur J Plant Pathol 117,141152.

Köksal, H., Atlı, A. ve Dağ, A. 1993. Çevrenin Bazı Nohut Çeşitlerinin Teknolojik Özelliklerine Etkileri. Tarla Bitkileri Merkez Araştırma Enstitüsü Dergisi, 2(1); 25-35.

Leo, A., Linde, C., Ford, R. 2016. Defence gene expression profiling to Ascochyta rabiei aggressiveness in chickpea, Theor Appl Genet, 129, 1333-1345.

Mart, D., Anlarsal,E; 2001. Çukurova Koşullarında Nohutta (CicerarietinumL.) Bazı Önemli Özellikler Yönünden GenotipXÇevre İnteraksiyonları ve Uyum Yeteneklerinin saptanmas1 Üzerine Bir Araştırma. Türkiye 4. Tarla Bitkileri Kongresi 17-21 Eylül 2001, Tekirdağ.

Mart, D., Cansaran, E., Karaköy, T., Ve Şimşek, M., 2003. Çukurova Bölgesinden Toplanan Yerel Nohut (CicerarietinumL.)
Populasyonlarının Bazı Önemli Agronomik Ve Morfolojik Özelliklerinin Belirlenmesi, Seleksiyonu ve Kantitatif Karakterlerin Belirlenmesi . Türkiye 5. Tarla Bitkileri Kongresi 13-17 Ekim 2003, Diyarbakır.

Özkan A., Kafadar F.N., Canan C., Mart D. 2015. Türkiye'de Yetiştiriciliği Yapılan Nohut Bitkisinde (Cicer arietinum L.) Yabancı Ot, Nodül Sayısı ve Rakım Arasındaki İstatistiksel İlişkiye Bir Bakış, 11. Tarla Bitkileri Kongresi 7-10 Eylül Çanakkale. Saxena, M.C., 1980. Recent Advences İn Chickpea Agronomy. In Proceedings Of The First International Workshop on Chickpea Improvement, 28 Feb- 2 Mar 1979. Icrisat, Hyderabat, India, s.89-96.

Slim, S.N., Saxena. M.C.,1993. Adaptation of Spring-Sown chickpea to the Mediterranean Basin.II. Factors influencing Yield under Drought, Field Crops Research, 34, 137146.

Singh, I.S, Hussain, M.A, Gupta, A.K., 1995. Correlation Studies Among Yield And Yield Contributing Traits İn F2 And F3 Chickpea Populations. International Chickpea And Pigeonpea Newsletter, 2, 11-13.

Singh, K.B., Williams, P.C. and Nakkoul, H. 1990. Influence of Growing Season, Location and Planting Time on Some Quality Parameters of Kabuli Chickpea. Journal of The Science of Food and Agriculture, 55(4); 429-441.

Tivoli, B., ve Banniza, B. (2007), Effect of ascochyta blight (Mycosphaerella pinodes) on yield components of single pea (Pisumsativum) plants under field conditions. Annals of Applied Biology, 129, 207-216.

Tripathi, H.P. and Singh, S.N. 1985. Performance of Chickpea Varieties under Different Dates of Sowing. International Chickpea Newsletter, 13; 11-13.

Wenhua D., Zhao X., Raju X., Davies P., Trethowan R. 2012; Identification of Ascochyta rabiei disease resistance in 
Doğu Akdeniz Bölgesinde İleri Çıkmış Nohut (Cicer arietinum L.) Hatlarında Kışlık Ekimde Verim ve Kalite Özelliklerinin Değerlendirilmesi

chickpea genotypes, Euphytica. 3,697-704. 